\title{
COMPARATIVE ADMINISTRATIVE LAW: ECONOMIC IMPROVISATION BY PUBLIC AUTHORITIES
}

\section{Fritz Morstein MarX $\dagger$}

Hard times beget social experimentation. The inevitable disintegration of economic optimism and psychological stability forces government into the front line of remedial action. The people, directly affected by the disruption of normal processes, are ready to sanction bold defiance of precedent in the management of public affairs. In such periods, they are least inclined to condone passivity on the part of their representative organs." That "something has to be done" is eminently clear to every one. It is usually far less clear exactly what has to be done. One general proposition, however, can be advanced without hesitation. In the economic era of machine production and in the political era of the nation-state, the natural prerogative of social redress lies with the largest unit of government rather than with its subdivisions. The programmatic design of planned activity in the conquest of industrial crisis must be reasonably uniform for the entire country. Otherwise it would be apt to remain ineffectual. Nationwide depressions cannot successfully be attacked locally. ${ }^{2}$

While this general proposition may be said today to be founded on an abundance of practical experience, there is nevertheless ample opportunity for public authorities, operating within local jurisdictions, to engage in economic improvisation. As long as such improvisation methodically implements wider programs, it may well be a wholly desirable demonstration of local initiative. The same cannot always be said of similar measures that are conceived without reference to a broader framework of concerted effort. Here, however, we shall concern ourselves with the economic implications only incidentally. The

$\dagger$ J.D., I922, University of Hamburg, Germany; Associate Professor of Political Science, Queens College; Lecturer in Government, Graduate School, New York University; author of Comparative Administrative Laze: $A$ Note on Revieze of Discretion (1939) 87 U. OF PA. L. REv. 954.

The author wishes to acknowledge assistance rendered in the preparation of this paper by a former Harvard student of his, Mr. James L. Kunen, member of the New York Bar, at present on the staff of the Division of Housing, Executive Department, State of New York.

I. Significantly, in his recent address on "Engineering in an American Program for Social Progress", Dr. Karl T. Compton, President of the Massachusetts Institute of Technology, has taken the government to task for having been "relatively inactive" in elaborating permanent solutions for our unemployment problem. THoRnton, ed., Science and Social Change (i939) 500.

2. The implications for local authorities are fully presented and examined by WeLls, AMERICAN Local Governarent (1939) passim, especially at I37 et seq. Here as elsewhere, the formula for the future must be intelligent and responsive cooperation between the municipalities and the Federal Government. 
theme of this article is rather the legal problem involved in the pursuit of home-made economic policies by public authorities servicing local areas. The approach will be, again, comparative and in terms of "situational" case analysis. ${ }^{3}$

The first case ${ }^{4}$ to be examined leads us into the law of public contracts. 5 The case deals with stipulations written by a municipal body into contracts let for the construction of an improvement; these stipulations aimed to mitigate the local unemployment situation. For our purposes, the motive itself is more important than the fact that it found expression in contractual form. What gives the case particular significance for our theme is the legal principle to be derived from it, not its special relevance to the law of public contracts. Let us remember, however, that the different levels of government control a considerable share of construction activity throughout the land. Quite obviously, in times of widespread chronic unemployment, contractual stipulations inspired by the thought of creating work are bound to retain their attraction to public bodies. ${ }^{6}$ The marked trend toward "special authorities" in recent years, ${ }^{7}$ moreover, has continued to broaden the poten-

3. For the methodological prototype, see Morstein Marx, Comparative Administrative Law: $A$ Note on Review of Discretion (I939) 87 U. OF PA. L. REv. 954 The most recent English literature on French and German administrative law is listed id. at $955, n$. 4 . The practical relevance of a comparative approach based on "situational" case analysis is outlined $i d$. at $955-956, \mathrm{n}$. 5 .

4. Bohn v. Salt Lake City, 79 Utah I2I, 8 P. (2d) 59 I (1932), 80 U. of PA. L. REv. II67.

5. The term is not free from ambiguity. Its meaning is more often implied than expressly stated. Donnelly, Law of Public Contracts (I922), for instance, does not give an exact definition of public contracts. He appears to use the term in application to any contract made by a body corporate and politic with an individual, a private corporation, or with another such body. To him, "a public contract is measured and governed by the same laws that control natural persons in contract matters, whether it be the nation, State, city, town or village". Id. \& 82 . There is room, however, for a terminological distinction between contracts among public bodies exclusively, and contracts made by public bodies with individuals or private corporations; and, in this latter group, further between such contracts as relate to the exercise of governmental authority (e. g., contractual settlement of governmental tax claims with the taxpayer), contracts let for public works and improvements (e. g., contracts belonging to the same category as that presented in our first case above), and contracts that are merely incidental to current operations of public management (e. g., purchase of office supplies). The most detailed grouping of public contracts is offered in JEzE, LES PRINCIPES GÉNÉRAUX DU DROIT ADMINISTRATIF (3d ed. I925-1936) vol. 3, 297 et seq., and vols. 4-6. On the power of dispensation in administrative law, see Note (1939) 87 U. of PA. L. REv. 20I. For the present purpose, it is not essential to define public contracts in terms narrower than implied by Donnelly, even though "the law of government contract differs at certain vital points from the law of public contract". Fresd, Research IN ADMINISTRATIVE LAW (1938) 33.

6 . It should not be overlooked that both in fact and in law there is a difference between such stipulations incorporated into public contracts in response to statutory mandate and identical clauses inserted without such express authorization. Statutory provisions of this kind are becoming more frequent. On the Walsh-Healey Act and the regulation of conditions in government contracts made under it, see Note (1937) 85 U. OF PA. L. Rev. 297 ; Shealey, Law of Government Contracts (3d ed. 1938) $\S 266$.

7. The tax and debt limits imposed by states upon their local governments have contributed to the proliferation of special districts and separate authorities. Under the 
tial area of public contracts, and with it the incidence of clauses either framed to meet specific policies of the public party or simply thoughtlessly onerous to the private party. ${ }^{8}$ No doubt, the legal questions arising from such clauses warrant greater attention than they have hitherto received.

The board of commissioners of Salt Lake City, in awarding contracts for the construction of a system of storm sewers, inserted into the contracts a number of unusual clauses. In the first place, the contractors had to agree that all construction materials, where there was no substantial difference in price to them, should be Salt Lake City products and manufacture; if not procurable in Salt Lake City, they should

New Deal, the flow of grants and loans made by the Federal Government to local units could not fail to accentuate this undesirable tendency. "A veritable mushroom crop of separate authorities has been the result." WeLls, op. cit. supra note 2 , at 9I. The new authority arose largely as "a legalistic device to enable a community, in debt to its ears and unable to borrow in its own name, to get money from Uncle Sam". Davis, Borrowing Machines (1935) 24 NAt. MUN. REv. 328. The legal status of such authorities can no longer be considered in doubt. Tranter v. Allegheny County Authority, 316 $\mathrm{Pa}$. 65, I73 Atl. 289 (I934). The question may well be raised whether or not the new authority is "a mere camouflage for improvident spending, an unnecessary and vicious decentralization of power and responsibility, leading to political abuses more abundant and harder to cure". Davis, supra, at 334. Whatever the reply, this much can be said in general: that the spread of separate authorities in the intrastate area imperils the organizational unity of local government and poses additional problems of governmental control. The danger of laxity, both fisca! and legal, is greater here than elsewhere. By its very character, the new authority, in promoting its purposes, is apt to rely on contractual arrangements rather than administrative power. Under the circumstances, the problem of special clauses in public contracts is today of increasing relevance. See note 5 supra.

8. One important category of special clauses in public contracts provides machinery for the non-judicial decision of certain questions that may arise in the execution of the contract. The borderline of validity is not always easily drawn. DoNNelly, op. cit. supra note $5, \S \mathrm{I} 52$, states the principal considerations as follows (his citations are omitted) : "It is an incident or term of every contract that the parties shall have the right to resort to a court of law for a settlement and adjustment of their disputes. Any provision to the contrary is void because in contradiction to the rest of the contract. . . Parties to a contract cannot, therefore, undertake an independent stipulation or agreement for the settlement and adjustment of all disputes by arbitration and deny jurisdiction to the ordinary tribunals provided by law. They will be permitted, however, by the same agreement which creates an obligation and gives a right of action for its nonperformance, to qualify the right, by requiring that before a cause of action shall arise certain facts shall be determined or amounts or values ascertained and arrived at, or that a third person must perform specific acts or determine certain questions, and they may make this a condition precedent to suit. Where a stipulation or agreement submits all future controversies to arbitration, whether the rights impaired flow out of the contract or independently of it, as from negligence, such provision is invalid as ousting the courts of jurisdiction. Agreements to submit all disputes to arbitration on questions of price, value, quantity or damage only, are valid and do not oust the courts. Provisions for arbitration which are indefinite, impracticable and unreasonable will not be sustained . - . But where is limits the questions to the amount or quantity of work to be paid for, and to all questions relative to fulfillment, it does not offend the rule and the certificate of the engineer in these respects is a necessary precedent fact to a recovery. In like manner provisions for the settlement of all disputes as to extra work will be upheld, if they merely qualify the right of action by providing a method under which certain facts shall be determined and amounts and values ascertained, as a condition precedent to action . . Though a contractor is not bound by the decision of an arbitrator in event of fraud or mistake so gross as to imply bad faith; and of course the same rule applies in favor of the public body when the acts of the arbitrator establish fraud." From this summary it is not difficult to see that court practice is neither oriented to well-established basic rules nor free from inconsistencies. 
be at least of Utah origin; only where the materials were not procurable in Utah could they be selected freely by the contractors. A second clause placed the contractors under obligation to do all excavating, loading, and back filling with hand labor; they were allowed to use teams and tractors only for plowing and loosening the materials to be removed. Thirdly, the contractors undertook to rotate all common labor and, so far as possible, all other labor once each week; the same workmen were not to be employed by them for more than two weeks in any month, and no worker was to be employed by them who during the month had had two weeks of work in any kind of employment, as long as other unemployed should be available. To facilitate the handling of the labor supply, the board of commissioners, on its part, agreed to set up a labor registration agency to list all those presenting themselves as able-bodied citizens of the United States and bona fide residents of Salt Lake City for the past year. Under a fourth stipulation preference in employment was to be given by the contractors to citizens of the United States or those having declared their intention to acquire citizenship, and particularly to residents of Salt Lake City, especially heads of families. Finally, the contractors were obligated to employ workers no more than eight hours a day, and to pay a minimum wage of $\$ 3.50$ per day.

The chief purpose of these special clauses was to create employment. Naturally, the board of commissioners was not unaware of the inevitable increase in construction costs. The increase altogether amounted to about $\$ 55,000$, while the total construction costs ran to some $\$ 600,000$. An earlier special bond election had authorized the city to secure this sum through a bond issue. The additional outlay, alleged to be "illegal and wasteful", gave rise to a taxpayer's suit aiming at a peremptory writ of prohibition to prevent the municipality from consummating the contracts. The Supreme Court of Utah granted the writ. ${ }^{9}$ Of the five members of the court, two joined in a dissenting opinion, one of them being the chief justice. Each of the other three justices offered separate reasons.

The first of these three, ${ }^{10}$ while affirming the statutory power of the municipality "to construct . . . sewers, and to regulate the construction . . . thereof", ${ }^{11}$ took issue with the special clauses imposed. He denied the city's authority to make the work of constructing the sewers subject to a condition which in no wise enhances the value or the merit of the sewers, but is inspired solely by a purpose of alleviating

9. Bohn v. Salt Lake City, 79 Utah I2r, 8 P. (2d) 59 I (1932), 80 U. of PA. L. Rev. I167. Sec Tooke, Judicial Decisions (1932) 2I NAT. MuN. Rev. 326

10. Bohn v. Salt Lake City, 79 Utah 12I, I22, 8 P. (2d) 591 (1932).

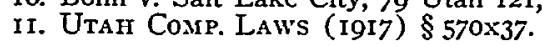


in part the unemployment situation, a wholly collateral condition to the objects and purposes sought by the construction of the storm sewers. According to him, in exercising the statutory power authorizing the city to provide a system of storm sewers, the board of commissioners, by insisting upon the labor stipulations, had been carried "far beyond the orbit of the power it is ostensibly asserting. Its action in this respect is wholly without authority and therefore illegal." 12 As to the additional cost resulting from the labor stipulations, the spokesman for the court had "no difficulty in coming to the conclusion that there is a plain diversion to the extent of $\$ 55,000$ from a fund specifically created by the sale of bonds for the purpose of constructing a system of storm sewers. . . ."13 Use of this sum to finance what was virtually a reemployment measure "cannot meet the sanction of the law".

Nor did the minimum wage clause prove acceptable to the court. Counsel for the municipality had placed reliance on two leading cases from other jurisdictions. ${ }^{14}$ These cases were declared "not at all apposite", since they had arisen in jurisdictions "where the charter powers of municipalities are far more comprehensive than is the case in this state". Conceding the argument that the city, had it decided to do the

12. Bohn v. Salt Lake City, 79 Utah 121, 128, 8 P. (2d) 59r, 594 (1932).

13. Id. at 129,8 P. (2d) at 594 .

I4. The two cases were Malette v. Spokane, 77 Wash. 205, I37 Pac. 496 (19r3), and Milwaukee v. Raulf, I64 Wis. Iร2, I59 N. W. 819 (I916). In the first mentioned case, a municipal ordinance providing for the eight hour day on public works was sustained against the contention that it conflicted with the public policy of the state and represented abuse of discretion. The court pointed to the State Constitution, art. II, $\S 10$, which conferred upon cities of the first class "the largest measure of local selfgovernment compatible with the general authority of the state". Malette case, at 224, 137 Pac. at 505. The charter placed no restriction on the city's power to contract for public improvements, except in connection with the procurement of supplies where it provided that the lowest bid be accepted. Further, a state law had established the eight hour day for state and local public works. Denying the relief asked for by a property owner, the court declared: "So long as the council acted in good faith, a general law or general ordinance not unreasonably increasing the cost of the work, would not invalidate the assessment." Id. at 230, I37 Pac. at 508. In the other case, a contractor had been arrested for violating a municipal ordinance limiting the working hours on public works. The ordinance was attacked as conflicting with the city charter; and as an unreasonable exercise of regulatory power if the charter authorized a regulation of working hours. Under a state statute, Milwaukee was empowered to regulate and administer its local affairs. Another statute provided for the eight hour day in all public works undertaken by the state. The charter required that all public contracts be let to the lowest bidder. No conflict between the ordinance and this charter provision was found by the court, which held that "When the specifications are complete, including the prescribed limitation as to the hours of labor for men to be employed upon public work, all bidders are on the same footing, and the one bidding the lowest sum is the lowest bidder within the meaning of the charter". Raulf case, at I86, I59 N. W. at 827. Power to enact the ordinance, on the other hand, was deemed inherent in the general welfare provision of the charter. Nor did the court see ground for declaring the ordinance unreasonable, since it appeared that similar provisions applied to public works carried on under federal and state laws. If the results of the ordinance were in any way mischievous, "the remedy rests with the people themselves. The remedy is legislative and political and is not to be found in the judicial field. The field of legislative discretion is broad, and as long as legislative bodies stay within its limits their enactments are the law of the land". Id. at I89, I59 N. W. at 828 . The arrest and conviction were upheld. 
work without letting it out, ${ }^{15}$ could have established the same minimum wage without hindrance, the court nevertheless refused to consider it "a true analogy to assume that it [the city] has the like right to dictate to its contractors the wages they must pay their workmen".

What of the employment preference to be given heads of families in Salt Lake City? Under the laws of Utah, ${ }^{16}$ such preference, on all public works, must be accorded "citizens of the United States, or those having declared their intention of becoming citizens. In each contract for the construction of public works the provisions shall be inserted to the effect that if the provisions of this section are not complied with the contract shall be void." In granting preference to family breadwinners in Salt Lake City, the board of commissioners, in the words of the court, "imposed a preference not embraced nor included in the statutes, and contrary to the statute restricted and limited the preference to heads of families of Salt Lake City. The city was, as we are, bound by the statute and by the policy so declared by the state, and which may not lawfully be enlarged or restricted. This provision of the contract cannot be sustained." 17

Both of the concurring opinions are considerably more elaborate. The next justice to raise his voice ${ }^{18}$ prefaced his reasoning with a survey of the background of the contested contracts. Persuading himself that "we judicially may notice the existence of the depression", he stressed three points: that during the bond election campaign there had been public reference to the reemployment opportunities afforded by the construction project; that, moreover, without the unemployment situation the work would not have been approved at the time; but that on the other hand the public had never been forewarned of any intention to carry out the project "on any basis other than an economical and practical cost". Quite apart from these facts, however, the justice, in construing its regulatory power over municipal works, denied the city any discretion concerning the imposition of the stipulations assailed in the suit. ${ }^{19}$

I5. Since the improvement was not "to be paid for out of the general funds of said city", the board of commissioners was in this case not required to solicit bids or to let contracts. UTA Comp. LAws (I917) \$ 819, as amended by Utah Laws I919, c. 14. Cf. Barnes v. Lehi City, 74 Utah 32I, 279 Pac. 878 (1929).

I6. UTAH CoMp. Laws (IgI7) \$ 4865 .

17. Bohn v. Salt Lake City, 79 Utah I21, I32, 8 P. (2d) 591, 595 (I932).

18. Id. at 132,8 P. (2d) at 595 .

19. As stated by Straup, J.: "It may readily be conceded that the commission [board of commissioners] had a sound discretion in estimating or approving estimates of the cost of the proposed and contemplated works, as to the kind and quality of material to be used, the manner in which the works were to be constructed and the character and workmanship thereof, the making and specifying of plans and specifications, accepting or rejecting bids for the proposed works and in respect of other particulars relating thereto; and that the exercise of such a discretion may not be judiciallly interfered with except upon allegations and proof of fraud or bad faith, arbitrariness, caprice, or abuse. Of course, where there is no power or authority . . ., no discretion or good faith is involved." Id. at $134,8 \mathrm{P}$. (2d) at 596. 
Could it be assumed that such discretion might be found within the broadest grant of municipal power, the "general welfare clause"? This statutory clause ${ }^{20}$ confers upon the board of commissioners, among others, the power "to appropriate money for corporate purposes only, and provide for payment of debts and expenses of the corporation; and to purchase, receive, hold, sell, lease, convey, and dispose of property, real and personal, for the benefit of the city, both within and without its corporate boundaries; to improve and protect such property, and to do all other things in relation thereto as natural persons; provided, that it shall be deemed a corporate purpose to appropriate money for any purpose which, in the judgment of the board of commissioners or city council, will provide for the safety, preserve the health, promote the prosperity, and improve the morals, peace, order, comfort, and convenience of the inhabitants of such city". ${ }^{21}$ The justice disarmed this clause in the instant case by limiting its scope to measures financed out of the city's general fund. ${ }^{22}$ The bonds in question "were duly authorized to construct the municipal improvement, and . . . were issued and negotiated stripped of the objectionable features complained of". Hence, he concluded, these moneys could not legitimately be diverted to such ends as were sought to be gained by the contractual stipulations under scrutiny.

Furthermore, since under the laws of Utah relief of the destitute was the concern of the counties, ${ }^{23}$ not the cities and towns, the concurring opinion even questioned the public character of the additional expense envisaged by the stipulations. Are not the beneficiaries of the intended reemployment measures a "class"? Indeed, " . . . the city, by imposing and requiring the performance of the complained of provisions in contracts let and to be let for the construction of the improvements, applied and will apply a substantial portion of the proceeds of the bonds to an object and a purpose which is not the essential character of the direct object of the expenditure, but, in a claimed advancement of public welfare, to a purpose admittedly to promote private interests of individuals out of employment, and by such provisions requiring the employment of a larger number of men than is necessary to construct the improvements, which essentially constitutes an applica-

20. UTAH CoMp. Laws (igry) $\$ 570 \times 2$.

2I. Italics added.

22. In his words, "Though it be assumed, which is not even contended for by the city, that, because of such general welfare clause, the city would be authorized or justified in its discretion to make appropriations out of its general fund for such a purpose, yet no one should so far be carried away by emotions or sentiment as to urge that the city would be authorized or justified in making such appropriations directly or indirectly out of a special fund not created for such a purpose". Bohn v. Salt Lake City, 79 Utah 121, 144, 8 P. (2d) 590, 600 (1932).

23. UTAH COMP. LaWS (I9I7) $\$ 1400 \times 40$. 
tion of a substantial portion of such proceeds to a private and not a public object . . . "24 It is well to remind ourselves that this was nearly five years before the Social Security Cases. ${ }^{25}$

More specifically, the concurring opinion held the city without power to establish by municipal action the eight hour day and to set a minimum wage on local projects : the former, because the eight hour day rested in Utah on statute, ${ }^{26}$ the latter, because no corresponding authority was conferred upon the city by statute. The scheme of employment preferences was considered invalid on parallel grounds. ${ }^{27}$ In short, and with much benevolent emphasis : ${ }^{28}$ "Laudable and proper enough it is for the city, because of unemployment conditions, to now construct the needed improvements, yet in the construction of them, to meet an emergency which has not a thing to do with . . . the construction and use of the improvements themselves . . . the city may not transcend its powers and do what admittedly it could not legitimately do without such emergency". ${ }^{29}$

The second concurring opinion ${ }^{30}$ adds little to the arguments set forth thus far. It is strongest in general doctrine. ${ }^{31}$ Our justice, for instance, saw in the hand labor clause ". . . a departure from the trend of modern civilization". 32 Is it surprising that he placed the spending of money for reemployment purposes on a par with a charity dona-

24. Bohn v. Salt Lake City, 79 Utah 121, I43, 8 F. (2d) 590,599 (1932).

25. See particularly Steward Machine Co. v. Davis, 30I U. S. 548, 586-587 (1937).

26. Utar Comp. Laws (I9I7) $\$ 3666$.

27. "The city may not nor may we enlarge and expand or restrict the statute to suit emergencies or conditions or particular cases not embraced within the statute. ..." Bohn v. Salt Lake City, 79 Utah I2I, 155, 8 P. (2d) 590, 604 (1932).

28. "There are so-called 'cracker-barrel philosophers' who, by their pseudo-philosophies, contend that the more difficult it is made to do a thing the better it is for those who have to sell labor, denounce the machine age and mass production, insist that modern labor-saving machinery diminish employment and enslave the many to make captains of a few, and to a large extent the use of them should be restricted or prevented, that mankind would be better off by causing work to be less productive and by requiring additional labor to accomplish the same thing, or by getting as little done as possible, all of which Professor Taussig in his treatise on Principles of Economics . . . has shown to be spurious. . . "Id. at I50, 8 P. (2d) at 602 . And again, it must “. . be noticed and not minimized nor lightly pushed aside that the primary and more important duty imposed upon the board and the city in spending taxpayers' moneys intrusted to them for a special and particular purpose was to so expend the fund as best to accomplish an efficient and proper construction of the improvement at an economical, reasonable, and practical cost and for the benefit of the taxpayers and the general public. The board was required to be as solicitous to promote and safeguard the interests of the general public and of the taxpayers as to promote interests of and give aid and benefit to a particular class". Id. at $154,8 \mathrm{P}$. (2d) at 603 .

29. Id. at $157,8 \mathrm{P}$. (2d) at 605 .

30. Id. at I58, $8 \mathrm{P}$. (2d) at 605 .

31. "Independent of statute, the city commissioners as trustees of the bond money are required to see that it is honestly, prudently, and economically expended for the construction of the storm sewer and for no other purpose." Id. at $164,8 \mathrm{P}$. (2d) at 607. And still more intriguing: "Prosperity bought upon credit must eventually in the end force many of those who now own their own homes or their own business to give them up and at the same time deter others from buying homes or setting up in business". Ibid.

32. Id. at $159,8 \mathrm{P}$. (2d) at 605 . 
tion? ${ }^{33}$ The tenor of his thought revolved around a petitio principii, to wit: "Our law does not recognize good faith or a lofty purpose as a legal excuse for diverting a special fund or any part thereof to a purpose other than that contemplated in the creation of such a fund. Exigencies do not change the rule. Nor is the rule relaxed by the pretense of keeping within it. The law looks to the substance, not to the form". ${ }^{34}$ The conclusion reached is implicit in the premise.

As contrasted with the views recorded for the court, the dissenting opinion, ${ }^{35}$ underwritten by the chief justice without comment of his own, displays greater compactness and consistency. We need not go into the review of leading decisions which it cites in its support, since none of them is directly applicable to the facts of our case. Suffice it to present the essential structure of argumentation from its opening passages: "The city has by delegation from the state plenary power to construct, maintain, and repair sewers. No limitations have been placed upon this power by the state . . . The possession of the power to do the work being conceded, a generous measure of its exercise will be permitted to the end that it may effectuate its purpose, and courts will not interfere except to see that the board has acted within the scope of its delegated power; that its discretion has not been abused; and that it was not actuated by fraud or bad faith. In its capacity as owner and proprietor the city is not hampered, where there are no statutory or constitutional restrictions, as to the manner or means to be employed in the construction of its public works. The conditions which an employer municipality may impose as to the manner of doing its work involves questions of policy which are within the discretion of the board of commissioners to decide. With respect to questions of policy the courts have nothing to do. The increased cost of the improvement is not of such magnitude as to imply fraud or bad faith. On this question the courts may inquire into the reasons and circumstances which actuated or explain the conduct of the board. When the reasons are considered, they show that the board is motivated by considerations of public welfare." 36

33. "So far as the plaintiff taxpayer is concerned, if he has no valid objection to the construction of the storm sewer under the proposed plan, I am unable to see how he could be heard to complain if the city were to construct the sewer in the usual way and then apply the money thus saved to some charitable or other purpose. In either event the property taxpayer will receive the same benefits and will be required to pay the same amount of taxes towards the satisfaction of the principal and the interest upon the bonds." Id. at $165,8 \mathrm{P}$. (2d) at 607 .

34. Ibid.

35. Id. at 166,8 P. (2d) at 608 .

36. As the closing part of the dissenting opinion aptly formulates it: "While the storm sewers which the city contemplates building are, and have been for many years, a necessity and will serve a useful and convenient purpose, nevertheless the board of commissioners determined to cause such public improvements to be constructed during this winter for the express purpose of relieving the unprecedented condition of unem- 
Turning from apologia to praise, the dissenting opinion underscored the beneficial motivation of the city fathers' course: "All such questions are questions of public policy which are for the city authorities to decide, and, unless they exceed their powers or abuse their discretion, the court will not substitute its judgment for theirs. This would be true even if we did not know the reasons which actuated the board in making the proposed contracts. With that information before us, we can say that, not only were the motives of the board of commissioners not bad, but were wholly good, and its action was taken for the avowed purpose of ministering to the general welfare of the community, and for this the board is to be commended and not condemned." 37

The decision has not been received with acclaim ${ }^{38}$ in all quarters. ${ }^{39}$ There are many minor aspects to the case on which opinions may differ. At this point, we shall confine ourselves to a delineation of the principal issue. The principal issue is not suggested by the remark of the second concurring opinion to the effect that "this court is committed to the

ployment now prevailing. It thereupon submitted its propsal to the people who voted the bonds for the purpose of constructing such storm sewers. The citizens were well advised, not by the specific terms of the proposal submitted to them for vote, but by declarations publicly made by the mayor and the board of commissioners and other public spirited citizens who were interested in providing employment for unemployed workmen in this locality, that, if the bonds were issued, the work would be speedily undertaken and diligently prosecuted, and that conditions would be written into the contracts providing for the use of the maximum number of laborers that could be well used on the enterprise. I do not pretend to say that the requirement of hand labor instead of machinery in the excavation and back filling for the sewers is ordinarily an economical or social policy. That is for the board of commissioners to say in the light of the conditions now existing. Society must solve the problems which arise from the use of modern machinery and efficient methods of production, not by discarding such instrumentalities, but by making use of them for the benefit of all. In view of the present emergency, the requirements for rotation of labor and that certain work be done by manual labor were prescribed in the exercise of a sound discretion. In view of this situation, we cannot say that the board abused its discretion, or that its action was arbitrary or capricious in any respect whatsoever. There is nothing in the record which points to bad faith or fraud. On the other hand, the action of the city authorities was well considered and under the circumstances wisely conceived. In such times as these, municipal authorities may well be subject to criticism and condemnation if they fail to move in the direction of doing all that lies in their power to meet the crisis of unemployment and as best they can alleviate the suffering of the people, not by charity or doles which is beyond their power, but by means of providing work on public improvements. The people do not want charity but do desire to support themselves and their families by honest labor. It would be an indictment of our civilization if public officers under such circumstances have no means of meeting the situation and particularly where, as here, the city authorities have proceeded only within the powers granted them by the Legislature and are not violating any law enacted to place a limit upon their powers." Id. at $187,8 \mathrm{P}$. (2d) at $6 \mathrm{I} 6$.

37. Id. at $185,8 \mathrm{P}$. (2d) at 616.

38. "In the instant case the municipal authorities overlooked two elementary principles: that all their powers must find a statutory warrant and that it is not their province but that of the legislative authority of the state to enlarge them by its declaration of public policy. An enabling statute or a validating act by the state legislature conferring the powers sought to be exercised would undoubtedly be sustained by the courts." Tooke, supra note 9 , at 327.

39. It was declared erroneous and deplored as another far-reaching intrusion into municipal autonomy in (I932) 80 U. OF PA. L. REv. II67. 
doctrine that a municipality has only such powers as are expressly conferred upon it by an act of the Legislature, and such powers as are necessary to the exercise of the powers expressly conferred". 40 For wide powers indeed were found to be delegated to the municipality in question. It is true the sedes materice is not the statutory provision concerning the "regulation" of municipal construction. ${ }^{41}$ The relevant authorization must rather be looked for in the "general welfare clause". ${ }^{42}$ The canon of strict interpretation is relaxed when it comes to the manner in which a municipality carries into effect powers expressly and clearly granted. ${ }^{43}$ Nor does the cardinal issue reside in the "class" character of the reemployment measures. In this matter, the practical experience of recent years has wrought striking changes, as attested by Mr. Justice Cardozo's reflection that it is in our day "too late . . . for the argument to be heard with tolerance that in a crisis so extreme the use of the moneys of the nation to relieve the unemployed and their dependents is a use for any purpose narrower than the promotion of the general welfare". ${ }^{44}$ No room is left for valid doubts.

It should be equally patent that the central issue does not arise from the nature of the municipal fund relied upon for financing the sewer construction. The actual diversion of special funds can be challenged on more than one ground. It is not a diversion in the proper sense, however, if a municipality, in devoting the special fund to its purpose, makes contractual dispositions to effect the giving of weight to broader municipal interests. The source of the revenue does not entitle the municipality to dispense with general considerations of public interest. Even if it operates with a special fund, the municipal administration is not only authorized but also obligated to incorporate into its public contracts all such clauses as safeguard and promote legitimate municipal concerns and the common interests of its citizenry. ${ }^{45}$ The "general welfare clause" 46 cannot be conceived of as applicable to municipal transactions that bear a relationship with the general fund, and as inapplicable to the execution of those projects which are financed out of a special fund. Within the wide categories of municipal activity

40. Bohn v. Salt Lake City, 79 Utah I2I, I60, 8 P. (2d) 59I, 605 (1932).

4I. See supra p. 428.

42. See supra p. 43 I.

43. "The rule of strict construction does not apply to the mode adopied by the municipality to carry into effect powers expressly or plainly granted, where the mode is not limited or prescribed by the legislature, and is left to the discretion of the municipal authorities. In such a case the usual test of validity of the act of a municipal body is, Whether it is reasonable? and there is no presumption against the municipal action in such cases." I Dilion, Municipal CoRporations (5th ed. Igri) $\$ 239$. (Italics are Dillon's.)

44. Steward Machine Co. v. Davis, 30r U. S. 548, 586 (1937).

45. "Public bodies have the right and the duty to insert in public contracts such reasonable stipulations as will tend to serve and protect the public interests. . . ." DoNNELLY, op. cit stpra note $5, \S \mathrm{I} 5 \mathrm{I}$.

46. See supra p. 431. 
embraced by it, the "general welfare clause" permeates all transactions, irrespective of the source of revenue.

The principal issue actually lies below the surface of our case. ${ }^{47}$ It involves a problem of differentiation. It may be presented in these questions: Did the board of commissioners, in writing the controversial clauses into the contracts, operate within the bounds of lawful discretion, although conceivably subject to errors in judgment? Or was the board responding to motives clearly outside the area encompassed by the "general welfare clause"? The opinions advanced for the court and the impressive dissent alike invite the conclusion that each of the justices aimed in the direction of this differentiaton. Yet the problem was not sharply defined, and the judicial logic stumbled more than once over the futile effort to equate the above differentiation with that between reasonable and unreasonable conduct. To the inadequacy of such an equation we shall revert in the closing part of our discussion.

II

Are there leading considerations to be derived for the solution of the major problem from foreign jurisdictions? The legal situation posed in the Utah case ${ }^{48}$ is not without a counterpart in French administrative and municipal law. A prefatory note, however, is in order. Municipal administration in France is traditionally overshadowed by the coordinating and supervisory power of the central authority. ${ }^{49}$ The French system of local government is heavily weighted toward the national interest. Thus municipal authorities must fit their initiative more cautiously into the program of the government than would be in harmony with American standards and practice. One may say that a

47. The governmental and administrative objectives of competitive bidding do not collide with the motives that went into the framing of the contractual clauses assailed in the suit. The principle of competive bidding admits of a combination with municipal policies aiming at factors outside the municipality's interest in the improvement itself, in so far as these policies are as such in accordance with the law. It is a somewhat forced argument when the first concurring opinion presents it as ". . . conceivable, because of such and of other complained of provisions, that some responsible bidders would even decline to bid or enter into contracts to do the work under such conditions and restrictions imposed and required". Bohn v. Salt Lake City, 79 Utah 121, 15I, I60 $P$. (2d) 591, 602 (I932). In our case, moreover, competitive bidding and the letting of contracts was not legally required. See supra p. 430.

48. See supra p. 426 et seq.

49. "The evolution of French local government institutions contrasts sharply with the story of 'local self-government' in Anglo-Saxon countries. Modern France is a unitary state with deeply rooted traditions of governmental centralization. These traditions have their origins in a thousand years of absolute monarchy and empire. Despite the democratic impact of the Great Revolution of 1789 upon the political development of the country, the substructure of centralized administration remained unbroken. Far from considering the advisability of 'federalizing' the governmental system, the Revolutionary Assemblies endeavored to obliterate such remnants of regional autonomy as were left in the 'hated' Ancien Régime. Since the primary impetus for the Revolution came from the populace of Paris and other large cities, the leaders of 'the Third Estate' were determined to destroy the historical particularism of those provinces which they felt might be prejudicial to the success of the new France." See Sharp, France, in Anderson, Local Governarent in Europe (I939) iog. 
true self-government has failed to materialize even under the Third Republic. The Municipal Code of $1884^{50}$ embodies the principle of enumerated powers rather than that of broad authorization to foster the general welfare of the local citizenry. The incidence of central supervision is extensive, ${ }^{51}$ although more recently the former conception of specific approval of municipal measures has tended to give way to the idea of a supervisory veto. ${ }^{52}$ These fundamental differences should be kept in mind in the discussion of the French case now to engage our attention, the Caillette case.

In its meetings of July $31, x 886$, and April $27, x 887$, the municipal council of Paris adopted a set of conditions to be inserted into all contracts subsequently let by it for the construction of public works. One of the conditions provided that a uniform wage be paid for each occupational category of workers employed. Another stipulation limited the hours of work to nine each day, with a day off every week. The government, in the exercise of its supervisory power, requested for its guidance an opinion of the Conseil d'Etat. The latter declared the conditions to be in conflict with the nature and in restraint of competitive bidding. Armed with this advice, the government annulled the council vote.

In a later meeting held May 2, I888, the municipal council substituted for the original uniform wage a minimum wage binding upon all bidders. The council retained the nine hour stipulation, ${ }^{53}$ although now limiting its application to one single group of workers. While the modifications did not touch the basic economic consideration, the government nevertheless acquiesced in the face of the council's conciliatory gesture, and refrained from pursuing another annulment. Consequently, a number of contracts were let on the basis of competitive bids

50. A very competent translation of the major parts of the French Municipal Code of 1884 can be found $i d$. at 202 et seg.

5I. "While the range of matters upon which the council may independently act has gradually been widened during the last half century, they are still unimpressive in comparison with the functions freely exercised by the councils of American cities. The municipal code lists twelve important types of action which require the approval of some superior authority before they can become effective. These functions fall into four major groups: (I) the purchase, mortgaging, selling, or leasing of municipal property ; (2) the appropriation of money, the fixing of tax rates, the borrowing of money, and the granting of concessions; (3) the establishment, naming, alteration. and closing of municipal streets, squares, parks, and gardens; and (4) the intervention of the commune in the domain of public utility enterprises, whether by direct operation or subsidy to private concerns, including, as types of activity, the supply of food, housing, welfare, or health services, or urban beautification. In the aggregate these functions constitute the very heart and substance of municipal activity." Id. at I44-I45.

52. "Until I926 specific approval was necessary in every instance. The reform legislation of that year, however, authorized 'tacit' approval in the following sense: if the prefect (or subprefect) does not indicate his disapproval within forty days after the council has voted, the measure shall be considered as having been approved. Similarly, where control by a national authority is provided, no action within three months is equivalent to approval." Id. at $\mathrm{I} 45$.

53. Including the provision concerning a free day every week. 
submitted in compliance with the special clauses. ${ }^{54}$ The awards found the formal approval of the Prefect of the Seine, as the agent of the central authority.

One of the contractors, while actually submitting the lowest bid, had raised reservations against the wage and hour stipulations, which he protested as illegal. As a result, he was eliminated from the competition by the municipal agency in charge of competitive bidding. In his recourse before the Conseil d'Etat he sought the annulment of the awards. The recourse prevailed. ${ }^{55}$ In its decision, the Conseil d'Etat had no reason to express itself on the general question of labor stipulations inserted into contracts awarded in consequence of competitive bidding for public works. The commissaire du gouvernement, in his presentation to the Conseil d'Etat, referred in this respect to the "oldest and most venerable" ministerial contract form for public works, the General Conditions for Bridge and Road Construction of November I6, ז866. He stressed the validity of the General Conditions and of those of its special clauses which imposed upon the enterpreneurs specific obligations as to the monthly payment of wages, the accumulation of an industrial accident and sickness fund, and the cessation of work on Sunday. He cited similar provisions from the contract form adopted by the War and Navy Ministries.

Nor did he doubt, generally speaking, the legality of similar clauses in municipal contracts, even of stipulations limiting, in view of serious economic conditions, the labor force to be employed by the contractor to workers living in the community. ${ }^{56}$ Still, as a matter of principle, he insisted that no municipality, in carrying out public works, "may impose on an entrepreneur the same obligations which a private individual having work done at his expense might stipulate. . . ." 57 The commissaire had little difficulty in making plain the legal considerations supporting the distinction. The individual, he pointed out, deals only with his private property. Municipal councils, on the other hand, administer public funds and thus dispose of the local taxpayers' money. With respect to the funds entrusted to it, no council may claim the same rights and the same freedom of disposal that is inherent in private property. Stipulations financially burdensome to the contractors would necessarily raise the cost of public works. The inference drawn by the

54. The stipulations were detailed to the point of providing a minimum wage also for piecework and overwork, and restricting the number of foreign workers. Each case of non-compliance was subject to a fine of Io francs, quite apart from contractual consequences.

55. Conseil d'Etat, March 21, I890, Dalloz Jurisprudence, I89r III. 8I.

56. He mentioned specifically this very case, and also restrictions applying to the employment of alien labor, such as were imposed by the municipal council in the controversial contracts. Ibid.,

57. Ibid. 
commissaire was that such stipulations, viewed by themselves, must consequently be regarded as prohibited. Moreover, all public works to be undertaken by local authorities are subject to special administrative regulation ${ }^{58}$ and administrative control, from which the cities are not at liberty to depart. In contrast with these far-reaching qualifications of municipal determination, individuals are entitled to follow their own private judgment.

From his analysis of the contractual stipulations imposed by the municipal council, the commissaire carried away the impression that the council "had in a certain way attempted to do the work of the legislator", 59 trying to regulate labor conditions in a manner comparable with the women and child labor legislation. In the first council deliberations concerning the issue, one member, justifying the measure as the official rapporteur, had indeed summarized the municipal motivation as follows: "The worker lives from day to day, lacking all credit; he finds himself confronted with an employer who has capital and credit, and who imposes his conditions upon the worker. It is hence required to protect the worker against the greater strength of the employer. Why in England does the government not intervene in these questions? It is because in that country there exists a workers' organization as strong as that of the employers, the trade unions. The same force, counterbalancing the power of capital, is lacking in France. Therein lies the significance of the intervention on the part of the city of Paris as far as its public works are concerned, and that of the government in the area of its own public works. The city of Paris represents the balancing power which the workers do not possess in their struggle against the employers." 60 Such policy touching matters of state, however, lies, in the eyes of the commissaire, distinctly outside the municipal sphere.

What is even more important: the French Parliament, conscious of the political orientation of the municipal council, had placed specific legislative restraints upon the latter's discretion relative to the contested contractual clauses. The national legislature, aware of the political intentions controlling the deliberations of the council, managed to counteract these tendencies in connection with a statutory authorization, addressed to the city of Paris, to employ municipal credit for public works. The credit act of December 3, 1888, a gift horse handsomely groomed, contained an express provision ${ }^{61}$ to the effect that the wage and hour stipulations in the city's contract form should be treated as without legal effect.

58. Especially the ordinance of November I4, I837, which prescribes in its art. I competitive bidding for all municipal public works. See Jèze, Théorie Générale dcs Contrats de l'Administration (I930) 47 REv. DU DRoIT PUBLIC 268.

59. Conseil d'Etat, March 2I, 1890, Dalloz Jurisprudence, I89I III. 8I.

6o. As quoted by the commissaire, ibid.

6r. Art. 2. 
On the particular question of the minimum wage, the commissaire saw no alternative for the Conseil d'Etat to adhering without qualification to the tenor of its earlier opinion submitted to the government in I888. ${ }^{62} \mathrm{He}$ considered the municipal wage policy a clear violation of the ordinance of November $14,1837,{ }^{63}$ arguing that the public bidding procedure made obligatory by the ordinance for all public works undertaken by local authorities would be jeopardized by the disputed minimum wage clause. The municipal measure would inevitably lead to a restriction of competitive bidding, deprive thereby the procedure of its key feature, and make price concessions of the contractors entirely illusory. He could not persuade himself that the substitution of a minimum wage for a uniform wage really changed the legal situation. To him, the cardinal factor was the interference of a municipal body with the determination of the worker's wage, a determination which, as he put it with disarming naiveté, must be "considered freely between employer and laborer". ${ }^{64}$ Any municipal intervention would conflict with "the fundamental principles of freedom of bargaining and freedom of work". ${ }^{65}$

The commissaire admitted that the nine hour clause posed a problem "much more delicate". ${ }^{66}$ He pointed out himself that the limitation of working hours was "the order of the day in all countries". ${ }^{6 t} \mathrm{Never}$ theless, the problem, in his words, was one arising "in the legislative rather than in the municipal domain". ${ }^{68}$ At any rate, the municipal council could not, without exceeding its power, link the nine hour clause inseparably with the untenable minimum wage stipulation. A severance of these two, on the other hand, would not have saved the clause. For, in the mind of the commissaire, the clause, in its practical effects, appeared as irreconcilable with the guiding idea underlying competitive bidding as did the minimum wage stipulation. The limitation of working hours, as he observed somewhat vaguely, would "merely cause a prolongation of the execution of the public works". ${ }^{69}$ Yet with all that to be said about the substantive side of the case, he was not inclined to urge redress in judicial forms. In his opinion, the matter belonged in the legislative realm. "The government could annul the illegal deliberations of the municipal council; the legislative power could intervene

62. See supra p. 437.

63. See supra p. 439.

64. Conseil d'Etat, March 2I, I890, Dalloz Jurisprudence, I89I III. 8I, 82.

65. Ibid. Both the formulation and the philosophy behind it seem to anticipate the classical reasoning enunciated in Lochner v. New York, 198 U. S. 45 (1905).

66. Conseil d'Etat, March 21, I890, Dalloz Jurisprudence, I89I III. 8I, 82.

67. Ibid. He referred to the statutory regulation in the interest of miners in England and Germany and cited the emphasis placed upon the question by "all economists". Ibid.

68. Ibid.

69. Ibid. 
as the last resort. Besides such intervention of the government and the Parliament, however, we see no room for a settlement by judicial procedure." 70

In spite of this recommendation to abstain from assuming jurisdiction, the Conseil d'Etat accepted the recourse of the aggrieved contractor. As to the substantive issue, the decision emphasized the close relationship between the council vote of May 2, I888, ${ }^{71}$ and the earlier deliberations annulled by the government for valid reasons, both as an encroachment upon the legally safeguarded freedom of labor contract ${ }^{72}$ and as a transgression of the boundaries of municipal power. In other words, the Conseil d'Etat, quite naturally, stayed on the same side of the fence that it had chosen in its previous opinion submitted at the request of the government. ${ }^{73}$ In addition to general doctrine, the Conseil d"Etat deduced the illegality of the controversial stipulations from the Act of December 3, I888, which explicitly pronounced the entire contract provision "réputée non écrite". ${ }^{74}$ Thus fortified by a double-track reasoning, the conclusion seemed to become impregnable: that the city council, by inserting the wage and hour stipulations into its contracts, had exceeded its lawful powers. If plaintiff refused to submit to the stipulations, this fact alone provided no legal motive for his elimination from the competition.

In comparing the French case with the Utah case, we must bear in mind, as submitted earlier, ${ }^{75}$ that the institutions of local government in France operate within a statutory authorization considerably narrower than is customary even among those of our cities not enjoying home rule in the technical sense. In the French Municipal Code, ${ }^{78}$ one does not find a parallel to the "general welfare clause" 77 which Salt Lake City invoked to justify its course of action. Hence the argument to be derived from the Caillette case is that from the minus to the majus. The broader lesson of the French case is, as we shall demonstrate, by no means wholly negative. Its positive doctrine, on the other hand, is of double significance for such jurisdictions as reflect the idea of local self-government in a fuller sense. An index is supplied in this respect by the very presence of the "general welfare clause".

70. Ibid.

71. See supra p. 437.

72. Acts of October 7/14, I790, and May 24, 1872. The first mentioned act goes back to the "right of work" proclaimed in the Déclaration des droits de l'homme of 1789.

73. See supra p. 437.

74. Art. 2.

75. See supra p. 436.

76. See supra p. 437.

77. See supra p. 43 I. 
Both with regard to the elimination of a contractor from the competition ${ }^{78}$ and with regard to special stipulations in general, there is no controversy among the French authorities as to the discretionary basis of the decision, irrespective of the public body making the decision. Nor is it a matter of conjecture that each public body, in the exercise of its discretion, must comply with the general principles governing administrative acts. ${ }^{79}$ As the conmissaire du gouvernement correctly pointed out in the Caillette case, ${ }^{80}$ no public authority, in framing its contract forms, enjoys the same freedom that is properly the private individual's. Every single contractual stipulation must rest on authorization, an authorization that may be specific or general. Each stipulation must therefore be supported by a legitimate public motive, more precisely, a public motive the pursuit of which falls into the sphere of activity assigned by law to the public authority in question. ${ }^{81}$ The Conseil $d^{\prime} \hat{E}$ tat inquires into such motivation as a question of law.

In the Caillette case, the decisive problem is the question of the extent of the sphere of municipal power. As a matter of policy the municipal council of Paris, unlike the board of commissioners of Salt Lake City, did not aim at conditions of local import; its controlling thought was not to secure social benefits for the population of Paris. Essentially, it intended to prod the government into passing labor legislation. Unquestionably, the city council's method of doing so by the assertion of municipal power over its contractors was inappropriate. Reliance on municipal power for this purpose carried the council beyond its proper municipal concerns. Moreover, as was made obvious to the council by the annulment of its earlier enactment and by the special law subsequently passed by the national legislature, ${ }^{82}$ the latter as well as the government were unwilling to respond to the hint coming from the municipal chamber. In fact, both had indicated concretely that there was, at least for the time being, a clear collision of national and municipal policy. This element too is missing from the Utah case.

In the absence of a municipal concern, the assertion of municipal power did not present itself as a legitimate qualification of the statutory principle of "freedom of bargaining and freedom of work". In France, as with us, civil rights are not construed as absolute; any restriction, however, as a qualification of the exercise of the right, must have a

78. See Jèze, supra note 58, at 316-317. See also id. at $261,265$.

79. See 3 JĖze, op. cit. supra note 5, at 223; Riesenfeld, The French System of $A d-$ ministrative Justice: $A$ Model for America? (1938) I8 B. U. L. REv. 400; Morstein Marx, supra note 3 , at 974 .

8o. See supra p. 438.

81. See Morstein Marx, supra note 3, at 976 .

82. See supra p. 439. 
foundation in lawful public concerns. In our case, such a foundation was lacking. This, of course, says little about the validity of contractual stipulations in general, ${ }^{83}$ and of labor stipulations in particular. Still, the law is not ambiguous on this point. The commissaire summarized it without error: municipalities are not barred from safeguarding their lawful interests in the framing of special clauses. He himself suggested as an example contractual provisions requiring the employment of local labor in order to alleviate the impact of economic adversity upon the municipality. ${ }^{84}$ No such conditions confronted the municipal council of Paris; they did confront the board of commissioners of Salt Lake City.

By advancing this example, however, the commissaire introduced a far-reaching modification into his cost argument. Certainly, for outof-town contractors to be limited to local labor would mean, as a rule, the necessity of higher bids. The logic of the illustration, in other words, is this: the cost factor represents a general barrier to labor stipulations, unless it is balanced by a municipal interest as substantial as that of economical management of public funds. After all, there are obvious future savings involved in many a municipal expenditure. It requires therefore no elaboration that the cost factor can be relied upon as a standard of prohibition only when and where the cost increase is not sustained with reference to any objectives properly pursued by a municipal body. Public authorities do not exist merely for the sake of fiscal thrift. What they accomplish is rather the fruit of constructive spending.

Let us also remind ourselves that the date of the Caillette case is I89o, and that since then the problem of adequate labor standards has acquired a vastly different complexion, here and abroad. ${ }^{85}$ The same general movement of public opinion has, in France, given rise to a noticeable expansion of municipal activities in the direction of economic providence. In a number of more recent decisions, the Conseil d'Etat has recognized the propriety of such motivation, once or twice in fact upholding a municipal measure solely on the basis of its contribution to the economic welfare of the community. In the Mariole case, ${ }^{86}$ for

83. Hauriou stresses the fact that the contractual stipulations imposed by the central departments engaged in public works often place heavy burdens upon the contractors. As to the question of ways and means of combating clauses excessively onerous to the entrepreneur, he suggests that "experience seems to reply in the negative". Haurrou, PrÉcts De Droit Administratif (12th ed. 1933) 935, n. 63. See also Conseil d"Etat, March 30, 1906, Dalloz, Recueil Périodique et Critique, Ig08 III, 5 ; TEXIER, LE CAHIER Des Clauses et Conditions Générates Imposées Aux Entreprises de Travaux Publics (7th ed. I93I).

84. See supra p. 44I.

85. For France, see Riesenfeld, Recent Developments of Frentch Labor Law (1939) 23 Mins. L. Rev. 407.

86. Conseil d'Etat, March 23, 1923, 93 Recueil 277. 
instance, the Conseil d'Etat sanctioned a decision of the municipal council of Havre concerning certain street reclassifications on the ground that the council had been guided "only by considerations of the commercial and industrial prosperity of the city and general interests of its population.", 87

\section{III}

A British case illuminating the legal situation involved in our theme, but more akin to the Caillette case than to the Utah case, arose some fifteen years ago from the wage policy of the borough of Poplar, one of the self-governing subdivisions of Greater London. ${ }^{88}$ Under the law, the borough council was authorized to avail itself, in the management of its borough affairs, of an appropriate staff of officers and workers, and to determine their remuneration as the council "may see fit". The wage scale adopted for the municipal workers was considered disproportionately high by the government auditor, one of the officials employed by the Ministry of Health in the discharge of its supervisory function over local authorities. The House of Lords, reversing the decision of the Court of Appeals, sustained the auditor against the borough council. Since the latter was dominated by the Labor Party, the litigation and its outcome caused much heated discussion. ${ }^{89}$ Naturally, we are not concerned here with the political implications.

The dilemma facing the courts in the Poplar case is mirrored in the reasons embraced by the different judges. Said Atkin, L. J., for the Court of Appeals, in pondering the crucial provision of the statute: "The first question that arises is whether this section gives the local authority unfettered discretion as to the amount of wages, provided they act bona fide; or whether their powers are limited to paying such reasonable salaries and wages as they may think fit. In the latter view the test of reasonableness would be an objective standard to which the council must conform. In coming to a conclusion on this point, it is desirable to recall the words of the section giving power to the local authority to employ such servants 'as may be necessary.' To comply with this section, must the council be able to satisfy some external authority, the auditor or the court, that all the servants employed are in fact necessary? Would it be open to the auditor to disallow the payment for four charwomen out of forty-four if he thought forty sufficient, or ten dustmen out of I44 if his experience led him to the belief that the work could be done by I34? It appears to me that the

87. $I d$. at 278. See also Chavanon's comment on a similar justification of a still more recent decision. (I937) 47 REv. DU DroIT PUBLIC I49, I50.

88. Rex v. Roberts, [I924] I K. B. 5I4, rev'd, [1924] 2 K. B. 675, rev'd sub nom. Roberts v. Hopwood, [ro25] A. C. 578 .

89. For a pointed analysis of the decision of the House of Lords, see LASKI, Studies IN Law aNd Politics (I932) 202-222. 
final decision upon this point must rest with the local authority, they acting in good faith. If this is true of the numbers and classes of servants employed, I think it must also be true of the wages, always assuming good faith." 90

In contrast with this construction, Lord Buckmaster, for the House of Lords, attempted to lay down an objective test. Commenting on the explanatory affidavit submitted by the borough council, he informed himself "that $4 l$. a week was to be the minimum wage for adult labour, that is without the least regard to what that labour might be. It standardized men and women, not according to the duties which they performed, but according to the fact that they were adults. It is this that leads me to think that their [the council's] action cannot be supported, and that in fact they have not determined the payment as wages, for they have eliminated the consideration both of the work to be done and of the purchasing power of the sums paid, which they themselves appear to regard as a relevant though not the dominant factor. Had they stated that they determined, as a borough council, to pay the same wage for the same work without regard to the sex or condition of the person who performed it, I should have found it difficult to say that it was not a proper exercise of their discretion. It was indeed argued that this is what they did, but I find it impossible to extract that from the statement contained in the affidavit. It appears to me, for the reasons which I have given, that they cannot have brought into account the considerations which they say influenced them, and that they did not base their decision upon the ground that the reward for work is the value of the work reasonably and even generously measured, but that they took an arbitrary principle and fixed an arbitrary sum which was not a real exercise of the discretion imposed upon them by the statute." 91

9o. Rex v. Roberts, [1924] 2 K. B. 695, 724.

91. Roberts v. Hopwood, [1925] A. C. 578, 589-590. Still more emphatic was his colleague, Lord Sumner: "The purpose, however, of the whole audit is to ensure wise and prudent administration and to recover for the council's funds money which should not have been taken out of them. If, having examined the expenditure and found clear proof of bad faith, which admittedly would open the account, the auditor further found that the councillors' evil minds had missed their mark, and the expenditure itself was right, then the expenditure itself would not be 'contrary to law' and could not be disallowed. Bad faith admittedly vitiates the council's purported exercise of its discretion, but the auditor is not confined to asking if the discretion, such as it may be, has been honestly exercised. He has to restrain expenditure within proper limits. His mission is to find if there is any excess over what is reasonable. I do not find any words limiting his functions merely to the case of bad faith, or obliging him to leave the ratepayers unprotected from the effects on their pockets of honest stupidity or unpractical idealism." Id. at 604. And finally, Lord Carson's plunge: "As regards the reasons already referred to, of Atkin, L. J., I am inclined to think, upon further consideration, that the admission that bad faith is not alleged or that the council exercised their discretion honestly has been misapplied. I do not myself know what these expressions are meant to cover, but, having regard to the statements made in the affidavit of the auditor that the council, in the exercise of their statutory powers, had not paid due regard to the interests of the ratepayers, whose funds they administered, had imposed unreason- 
One cannot read Lord Buckmaster's deduction without sensing the strain in its structure. Is it not the very purpose of a minimum wage schedule to provide a floor beneath which compensation for labor is not permitted to drop? If this is true, it appears plain that a graduation according to type of work performed is neither an essential characteristic of a minimum wage measure nor required from the point of view of sound municipal finance. The establishment of a minimum wage inevitably bestows greater benefits upon the lowest income groups. A uniform minimum wage is still less favorable to the upper brackets of labor, and hence may lead actually to a saving for the municipal treasury, as compared with a graduated scheme setting special rates for the top groups.

Even more arresting is the fashion in which Lord Buckmaster extricates from the affidavit of the borough council his personal hunch as to the council's real motive, irrespective of the explanation urged upon him earnestly by the council itself. There is little to commend this kind of inquisition, which in effect substitutes the court's discretion for that of the elected council. ${ }^{22}$ In the wise phrase of Scrutton, L. J.: "A wide margin should be allowed for error of judgment, not amounting to misconduct, or for deliberate policy, not being illegal, with which the auditor cannot interfere". ${ }^{93}$

Before we examine the implications of this proposition, let us indicate what it does not encompass. A Swiss case within the area of our investigation may serve as the prototype. A contractor, duly armed with a municipal building permit, had begun construction for a private party. Use of a steam shovel aroused protests among the working population. The municipal building bureau, stirred by the protests, urged the contractor to discontinue work with the steam shovel, pointing to the unemployment problem in the community. Meanwhile, the local union called for a protest meeting at the site of the construction.

In an emergency meeting of the municipal council, its socialist member announced union reprisals in the form of a forcible removal

able charges upon the funds and made payments which were far in excess of those necessary to obtain the services of those required and to maintain a high standard of efficiency, and were thus in reality gifts to their employees in addition to remuneration for their services, $I$ find it difficult to come to a conclusion that the admissions referred to meant anything more than that the council honestly thought that they were entitled to take the course which they did take, and in my opinion it was open to the auditor, upon coming to the conclusions as stated in his affidavit, to draw the inference that the board were not engaged in merely fixing a rate of wages, but were affected by a consideration which could not be held to come within the ambit of the discretion entrusted to them." Id. at 617-618.

92. Even though the conflict itself arose between the auditor and the borough council, there is manifest in the decision of the House of Lords an ominous tendency toward fiscal superintendence of local authorities. In a sense, the decision testifies to the growing importance of the permanent ministerial personnel in the conduct of local government. This factor is not sufficiently stressed by Laski in his critical comments. See LASKI, loc. cit. supra note 89.

93. Rex v. Roberts, [1924] 2 K. B. 695, 719. 
of the shovel from the site, unless the council would require the contractor to cease work with it. The council, "complementing" the original building permit, issued this prohibition. The contractor brought recourse before the cantonal council of state, which upheld the prohibition as a measure destined to improve employment conditions in the locality and thus to maintain public order. At the same time, the council of state passed a decree prohibiting the use of mechanical shovels within the canton, except by specific permission of the municipal authorities. On appeal, the Federal Supreme Court reversed the decision and annulled the decree. ${ }^{94}$

The court took for its point of departure the constitutionally guaranteed freedom of trade and industry. ${ }^{95}$ Under the Federal Constitution, the cantons may take police measures for the protection of public order, but they have no authority to impose regulatory restrictions upon the freedom of trade and industry. The court considered that the decisions of the municipal council and the cantonal council of state were primarily directed toward the unemployment problem. Any such effort to correct by police measures the effects of competition between manual labor and machine labor was held irreconcilable with the Federal Constitution. All preventive or repressive measures taken in the exercise of the cantonal police power must be "appropriate, adapted to the circumstances, and directed against those who imperil the public order".

In the case at hand, the authorities were entitled to take steps against those threatening to disturb the peace, but not against the contractor. At best, a temporary prohibition could have been justifiable, until the excitement had died down or the authorities had been able to restore order effectively. The mere fear of disturbances is legally irrelevant. Being in contradiction with the Federal Constitution, the assailed decisions cannot be based on the cantonal constitution or on municipal regulations concerning police supervision over construction work. The municipal council might have lawfully prohibited the use of the steam shovel had its employment threatened the health or the safety of the workers or the public. The council as a police authority was, however, without power to take such a step in response to local feeling or in the interest of relieving unemployment. ${ }^{96}$

94. Travelletti c. Conseil d'Etat du Canton du Valais, June II, 1937, 63 (I) Entscheidungen des Schweizerischen Bundesgerichts 213.

95. Switz. Const. Art. XXXI.

96. The appeal correctly termed the attacked decisions "arbitrary". Travelletti c. Conseil d'Etat du Canton du Valais, June II, I937, 63 (I) Entscheidungen des Schweizerischen Bundesgerichts 213, 216. 
The Swiss case illustrates a legal principle common to all Continental European systems of administrative law. In brief, it is this: the police is not empowered to pursue economic policy..$^{97}$ It follows that police authorities may not take measures in order to protect manual labor against the displacement by technological equipment; or in order to mitigate unemployment; or in order to maintain the existing level of employment. ${ }^{98}$ These rules, however, while recognized by France's droit administratif and the German doctrine of Verwaltungsrecht alike, find their justification in the specific character of police tasks : the preservation of public order. In other words, the police power, in Continental European terminology, is a concept far narrower in meaning than is true of American usage. The concept is confined to the area of public safety.

No doubt the restraints imposed upon the police, as far as the quest of economic objectives is concerned, entirely accords with practical considerations. In the first place, under the auspices of representative government, we can safely curb police benevolence because issues such as that of machine versus man are adjudged with greater authority in the forum of the elected legislature. Second, in the era of functional specialization, ${ }^{99}$ administrative accountability and control, as much as the "rule of law", require police authorities to refrain from roaming beyond their province. And third, there is little in the general character of police work that would appear particularly conducive to sound economic perspective. ${ }^{100}$

A sharp line of distinction, however, must be drawn between police decisions in this narrow sense and policies adopted by municipal legislatures. In the Swiss case, it is true, the contested measure was taken by a municipal council. But here the council acted as the police authority, not within the area of municipal self-government. Exercising its police power with both eyes on economic issues, the council permited itself to be pulled across the boundaries of lawful motivation. ${ }^{101}$ From the point of view of office psychology, it is interesting that a leading authority on Swiss constitutional law ${ }^{102}$ has found the lay element in Switzerland's administrative structure more inclined to

97. See Drews and Lassar, Allgemeines Polizeirecht, 2 Von Brauchitsch, VerWaltungsGesetze für PreUSSEN (22d ed. 1932) I, I9.

98. 38 Entscheidungen des Preussischen Oberverwaltungsgerichts 291, 300. seq.

99. See Morstein Marx, The Bureaucratic State (1939) I Rev. of Pol.Irrcs 457 et

100. As Jèze observes for France, "bureaucrats have very inadequate experience in practical economic matters". Jèze, supra note 58 , at 262 .

101. See Morstein Marx, supra note 3, passim.

102. Fleiner, Schifeizerische und Deutsche Staatsauffassung (igzg) I5. 
swing the stick of government power than he saw borne out in "civil service states" such as Germany prior to the advent of Hitler.

As to the scope of municipal self-determination, pre-Hitler Germany, on the other hand, respected the "universality rule". The rule implied "local freedom of initiative in the pursuit of the common good", ${ }^{103}$ irrespective of special legislation. Municipal authorities were "placed in a position to include in their activity any purpose conducive to the promotion of the general welfare or the material and other interests of their citizenry" ${ }^{104}$ Under the "universality rule", the presumption of law was "in favor of municipal power to deal administratively with local problems and set up appropriate agencies, save for those spheres recognized as the realm of central authority". ${ }^{105}$ It is not surprising that during the economic depression of more recent years the "universality rule" gave rise to extensive municipal reemployment measures. ${ }^{106}$ The legality of individual features of these measures did not meet judicial challenge.

To revert to the general plane: aside from the German example, there is much to be said for local autonomy freer of court superintendence than it is today in the United States. "Self-government cannot be learned except by the trial-and-error method." 107 Or, in the words of an outstanding municipal executive of Republican Germany, "Local governments must have freedom even to do occasionally something foolish". 108 The need for reemployment programs, moreover, is as acute today as it was in the initial phase of the Great Depression. As long as a systematic and fully effective attack upon the unemployment problem on the part of the Federal Government has not materialized, ${ }^{108}$ local authorities will be pushed into improvisation. ${ }^{110}$

I03. See Morstein Marx, Germany, in Anderson, op. cit. supra note 49, at 253.

I04. Kormann, Einführung in die Praxis des DeUtschen VerwaltungsRECHTS (2d ed. by List, I930) II8.

105. Morstein Marx, Germany, in ANDERSON, op. cit. supra note 49, at 253.

106. See Kraus, Work Rertef in Germany (1934) passim, especially go et seq.

107. See Wells, op. cit. supra note 2 , at 120 .

108. Cited in Morstein Marx, Germany, in ANderson, op. cit. supra note 49, at 253.

109. We may well ponder the following statement by Park Commissioner Robert Moses in New York: "The WPA is a decaying institution. It is a crime against the men themselves to continue it much longer. Many of them will never be able to compete with their fellows in private industry; others may still be salvaged before it is too late. Generally speaking, relief projects are getting thinner and poorer throughout the country. There is not enough money for plans, material, equipment, competent supervision, and skilled labor to do worth-while things. This cannot be proven in the face of the anguished cries of supporters of the system, but the average citizen knows it is so and cannot be talked out of his dislike of it. Work relief cannot be dropped all at once. It is being cut down gradually, but even this is not the answer. The answer lies in a new approach to public works by contract and by government loans to wholly or partially self-liquidating public and semi-public projects and, above all, in the prompt application of stimulants to the resumption of private business." MOSES, THEORY AND Practice in Politics (1939) 74-75.

I10. As a municipal manager has put it: "Now (I939) many cities find their public works really needing more attention than local finance will be able to provide in a decade. As the relief situation continues, the physical condition of public works be- 
We said at the beginning that such improvisation has little to commend it from an economic point of view. ${ }^{111}$ There are, however, other considerations to be taken into account in reaching a conclusion concerning the legal side of the problem. One of these is encountered in the apodictic statement that in the execution of public works the municipality occupies the same position as a private individual contracting for identical purposes with the entrepreneur. The assertion is not devoid of what looks like a precedential basis, ${ }^{112}$ but it conflicts with broader principles.

For it is irreconcilable with the character of public authority to place governmental bodies on a par with the individual as far as freedom of action is concerned. The individual is entitled to free choice of conduct under the law. This freedom is his as a matter of right. It is a freedom qualified in its concrete manifestations by the limitations that arise from the lawful exercise of administrative power. It is a freedom yielding to the legitimate demands of the public interest, without ever surrendering its substance. Governmental bodies, on the other hand, as guardians of the public interest, are held to their specific mandate. The scope of their activity is not derived from any rights such as buttress the legal status of the individual. Their initiative is never free, but conditioned on authorization. ${ }^{113}$ They may not pursue an end alien to the purpose underlying their creation.

All governmental bodies are instrumentalities of the public interest. As such, they are dominated by the concrete objectives to which they have been dedicated. Administrative authority, therefore, even where it is granted in broad language, does not admit of being construed as freedom of option comparable to that enjoyed by the individual. Authorization is always for a defined or definable objective. In this respect, all governmental bodies are establishments designed for social use. They find their ultimate justification in serving the interest of the individual as a member of the organized community. The service function of administrative power has nothing in common with the autonomy of private motivation. Individual right and regulatory power are not of the same fabric. They are counterparts, mutually limiting each other. The exercise of power is controlled by explicit or implicit statutory directives, not by volition invoking right.

comes worse. The saving grace is that certain kinds of work, requiring a large percentage of man power, have been projected into the future to such an extent as to relieve communities of such construction financing for a long time." Hodges, CITY MANAGEMENT (1939) 523. Cf. in general on the organizational and managerial side, STONE, The Management of Municipal Public Works (1939).

III. See supra p. 425 .

II2. The following leading cases are usually cited: Atkin v. Kansas, I9I U. S. 207 (1903); People v. Crane, 214 N. Y. 154, 108 N. E. 427 (I915); see Note (1915) I5 CoL. L. REv. 263 .

II3. See Morstein Marx, supra note 3, passin. 
True enough, "it is one of the pillars of modern political theory that governmental power must operate in the interest of the community at large and thereby justify itself'. ${ }^{114}$ But the interest orientation of government does not emerge simply from the ends served by government; it arises in the first instance from the revocable mandate under which government carries out its policies. Authorization and service orientation of government maintain therefore a reciprocal relationship. It is from authorization that the service function of government is derived. And what in this respect applies to government in general applies as well to all public bodies, large and small. ${ }^{115}$

In an earlier paper ${ }^{116}$ I have attempted to outline some of the rules that must be deduced from the key position occupied by authorization in the entire domain of public administration. In particular, I tried to delimit the area of lawful motivation for the exercise of the licensing power. The test proposed was not the administrator's good faith nor his conception of sound and practical procedure, but the nexus between the discretionary act and those objectives encompassed in the statutory authorization. "The question whether or not a discretionary act has overstepped these legal boundaries is a question of law and not of discretion." 117 In deciding such questions, however, judicial bodies depend on a considerable degree of insight into the administrative process. If the judges, as is the case in the composition of Continental European administrative courts, are largely drafted from the administrative service, and if, in turn, the university training for the adminis-

I14. In the words of a Danish authority on administrative law: ANDERSEN, UNGÜLTIGE VERWALTUNGSAKTE (I927) 258.

II5. A general authorization qualified by provisions requiring a regulation of the manner in which the authority is to be exercised is conditioned on the adoption of such a regulation. To give an illustration, a Florida statute contains the following: "The City Manager shall make all purchases for the City in the manner provided by ordinance and shall, under such rules and regulations as may be provided by ordinance, sell all personal property of the City not needed or that may have become unsuitable for public use. Before making any purchase or sale, the City Manager shall give opportunity for competition under such rules and regulations as may be established by ordinance." Fla. Spec. Sess. Laws 193I, c. 15505, § Iog. (Italics added.) In Brown v. City of St. Petersburg, III Fla. 718, I53 So. 140 (I933), the Supreme Court of Florida held that in the absence of a purchasing ordinance the city manager could not be considered authorized to make any purchasing contracts; that on the other hand, in making purchases on the basis of a purchasing ordinance, the city manager was not required to insure competition, unless directed by ordinance to do so, "since the last clause of this section is merely a permissive limitation that may or may not be imposed by ordinance". The court, in other words, did not read the "may" in the closing passage as "shall". On this point, one authority comments as follows: "The court must have concluded that under the peculiar public policy of the state, declaring that all cities organized under the commission system are primarily to be regarded as business corporations (Kaufman $v$. City of Tallahassee, [1922] 84 Fla. 634, 94 So. 697), the legislature intended to leave it discretionary with the commissioners to what extent they should limit this power of the city manager." Tooke, Municipal Powers, I MUNICIPAL YEAR BOoK (I934) 57, 58. The present writer inclines to the view that the result reached by the court does not necessarily rest on the above mentioned "public policy of the state".

116. See Morstein Marx, sipra note 3.

117. I RUCK, Schweizerisches Verwaltungsrecht (2d ed. 1939) I66. 
trative career stresses juridical disciplines ${ }^{118}$ including administrative law, ${ }^{119}$ judicial inquiry into administrative motivation will not be illinformed and haphazard. The French Conseil d'Etat, for instance, has justly been acclaimed for its "circumspection" 120 in the examination of the administrator's mind. The same may well be said of Prussia's Supreme Administrative Court.

Indeed, otherwise there might be a real danger that "the spontaneity of the discretionary power is killed". ${ }^{121}$ The administrator "must respect the law, but must not thereby be imprisoned by too strict rules that would impede his action: in order to have a just administration one would have no longer an efficient administration. That would mean to drift from Charybdis to Scylla". ${ }^{122}$ What is suggested here concerning the administrator applies with double force to municipal authorities exercising the powers of self-government. As Atkin, L. J., expressed it in the Poplar case: "Surely it is not too much to say that in matters which directly and mainly concern the people of the county, who have the right to choose those whom they think best fitted to represent them in their local government bodies, such representatives may be trusted to understand their own requirements better than judges". ${ }^{123}$ In fact, the soundness of this argument has found recognition by the same court that supplied us with our starting point: the Supreme Court of Utah. ${ }^{124}$

II8. For a historical survey, see Friedrich, The Continental Tradition of Training Administrators in Law and Jurisprudence (1939) II J. MoD. HIST. I29 et seq. See also Morstein Marx, Civil Service in Germany, Civil Service Abroad (i935) 2io, 223 et seq.

IIg. As the entire body of law controlling the conduct of public administration.

120. Hauriou, op. cit. supra note 83 , at 444 .

12I. Id. at 443 .

122. Waline, Le pouvoir discrétionnaire de l'administration et sa limitation par le contrôle jurisdictionnel (1930) 47 Rev. DU DroIr PUBLIC 197, 223. (Italics are Waline's.)

123. Rex v. Roberts, [1924] 2 K. B. 695, 727.

124. Shulte v. Salt Lake City, 79 Utah 292, 10 P. (2d) 625 (I932). In this case, a taxpayer sued to prohibit the city from proceeding with the performance of a contract for the construction of a storm sewer on the ground that the contract had not been awarded to the lowest bidder. Here, too, because of the nature of the fund, no competitive bidding was required by statute, see supra p. 430 . On a $\$ 118,000$ project, the winning bid exceeded the lowest by $\$ 267.36$. The lowest bidder, however, was a California resident, who owned no property in Utah, although he enjoyed a good reputation as a contractor. The accepted bidder resided in the city, was financially responsible, owned ample equipment, and had satisfactorily completed 29 contracts for the city, 13 involving sewer construction. Holding the award to be valid, the court said: "Independent of any statute regulating the awarding of contracts for the construction of public improvements, the city commissioners are required to act in good faith, without fraud, collusion, corruption, or palpable abuse of discretion, and with due fidelity to the public interests... The general rule deducible from the adjudicated cases and text-writers is to the effect that, where there is no statutory limitation upon the power of the proper officers of a city to let contracts for public improvements, such officers have a broad discretion. Courts refuse to interfere with their control of the matters so long as they do not exceed the power delegated to them, or invade private rights or act in bad faith or palpably abuse their discretion. A similar rule prevails in most juris- 
While on the one hand discretionary measures must retain for their validity a distinct nexus with the objectives encompassed in the statutory authorization, there remains on the other hand a latitude of judgment as to the emphasis to be placed on different relevant factors in framing the discretionary decision. More than that: discretion may err, may misjudge, may rest on wrong assumptions-all depending on the standard of reconsideration. Faulty discretion is not identical with abuse of discretion inspired by improper motives. The latter is lawlessness, for the objective of the discretionary act transcends the scope of authorization. The former operates within the statutory mandate, but, viewed from a different vantage point, fails to reach its lawful objective or approaches it either too meekly or too fervently or goes through motions more extensive than appear to be warranted, to give only a few examples. At bottom, we are faced here with a conflict of judgments: that of the insider against that of the outsider. And the outsider, in the last analysis, is the court.

The situation is brought into sharp relief in the Utah case. ${ }^{125}$ The "general welfare clause" 126 provided the board of commissioners of Salt Lake City with ample discretionary power to determine the modus operandi of the public works to be undertaken, quite apart from the "regulation" of the construction in the narrow sense. ${ }^{127}$ Yet the way the board, in designing the modus operandi, gave recognition to the local unemployment problem collided with the notions of municipal economy entertained by the court. The dissenting opinion put the issue in its correct perspective: "I do not pretend to say that the requirement of hand labor instead of machinery . . . is ordinarily an economical or social policy. That is for the board of commissioners to say in the light of the conditions now existing." 128 There is wisdom in such selflimitation.

The general rule, universally applied in Continental European administrative law, is well stated in one of the most progressive codes of administrative justice, the Administrative Judicature Act adopted in I92 I by the city-state of Hamburg, Germany. ${ }^{129}$ Its Section 46 reads: "In so far as administrative agencies are authorized by statute to exercise discretionary power, action cannot be brought, except for special

dictions under statutes which require that contracts for public improvements be let to the lowest responsible bidder. In such case the officers whose duty it is to award the contracts are vested with discretion in determining who is the most responsible and best bidder. . . Id. at 299,300 , 10 P. (2d) at 628 .

125. See supra p. 426 .

I26. See sipra p. $43 \mathrm{r}$.

I27. See sipra p. 428.

I28. Italics added. See supra p. 433.

I29. For the (abridged) text of the law, see Morstein Marx, Die Verfassungs- und Verwaltungsrechtsentwicklung in den drei Hansestädten Hamburg, Brenten und Lübeck, I9I8-I928 (1928) I6 JAHRBUCH DES OFFENTLICHEN RECHTS 5I, 75 et seq. 
statutory provisions, on the ground that sound discretion would have required a different decision". The clause is reminiscent of an earlier decision of the Prussian Supreme Administrative Court which enunciated the principle as follows: "The administrative court cannot superimpose its discretion over that of the [administrator] . . . provided only that the [administrator] has been guided discernibly by objective [administrative] considerations". ${ }^{130}$

Patently, the distinction is not between reasonable and unreasonable exercise of discretion. Reliance on these categories invites misunderstandings as to both the extent and the character of judicial control over discretionary measures. It is not the task of the judge to identify himself with the results of administrative discretion; to accept for himself these results as reasonable; or otherwise to invalidate the measure as unreasonable. Lawful exercise of discretion may, as we saw, cross the border between reasonableness and unreasonableness, as drawn by the court, without becoming altogether irrational and hence arbitrary. The mere conflict of judgments conditioning the concrete manifestation of discretion is not to be resolved arbitrarily in favor of the court.

130. 29 Entscheidungen des Preussischen Oberverwaltungsgerichts 442, 446. 